\title{
Temperament and Character Traits of The Patients with Type 2 Diabetes
}

\author{
Elif Biter ${ }^{1}$, Erman Bagcioglu², Bulent Bahceci³ ${ }^{3}$ Ali Ozer ${ }^{4}$, Mesut Ozkaya ${ }^{5}$, Mehmet Fatih Karaaslan
}

\section{ÖZET:}

Tip 2 diyabet hastalarında mizaç ve karakter

Amaç: Bu çalıșmadaki amaç tip 2 diyabet hastalarında mizaç ve karakter boyutundaki faklılıkları deg̃erlendirmekti.

Yöntem: Mizaç ve Karakter Envanteri, MontgomeryAsberg Depresyon Deg̃erlendirme Ölçeg̃i, Hamilton anksiyete ölçeg̃i tip 2 diabet hastalarına ve kontrol grubuna uygulandı.

Bulgular: Anksiyete ve depresyon skoru diabetli hastalarda anlamlı olarak yüksekti ( $p=0.0001$ ve $p=0.009$, sırasıyla). Mizaç ve Karakter envanterine göre, zarardan kaçınma-çabuk yorulma ve dermansızlık, kendini yönetme-beceriklilik, ișbirliḡi yapma-yardımseverlik skorları hasta grubunda anlamlı olarak yüksekti ( $p=0.001, p=0.004$, $p=0.040$, sırasılyla).

Sonuç: Bizim araştırmamızda tip 2 diyabet hastalarının anksiyete ve depresyon skorlarının kontrol grubundan anlamlı olarak yüksek oldug̃u ve mizaç ve karakter envanterine göre de çabuk yorulma ve dermansızlık, beceriklilik, yardımseverlik alt gruplarında her iki grup arasında farklılıklar bulunmustur.

Anahtar sözcükler: tip 2 diyabet, mizaç, karakter

Journal of Mood Disorders 2012;2(4):153-9

\section{ABSTRACT:}

Temperament and character traits of the patients with type 2 diabetes

Objective: The aim of this study was to evaluate the differences among dimensions of temperament and character within type 2 diabetes patients.

Methods: Temperament and character inventory, Montgomery-Asberg Depression Rating Scale, Hamilton Anxiety Rating Scale were administered to type 2 diabetes patients and control groups.

Results: Anxiety and depression scores were significantly higher in patients with type 2 diabetes $(p=0.0001$ and $p=0.009$, respectively). According to inventory, the scores of harm avoidance-fatigability, self directednessresourcefulness, and cooperativeness-helpfulness of patients were significantly different from controls $(p=0.001, p=0.004$ and $p=0.040$, respectively).

Conclusions: Our research findings indicate that the patients with type 2 diabetes differ from the control group members in terms of higher levels of anxiety and depression as well as the temperament and character traits of fatigability; resourcefulness and helpfulness.

Key words: type 2 diabetes, temperament, character

Journal of Mood Disorders 2012;2(4):153-9
${ }^{1} \mathrm{MD}$, Departments of Psychiatry, Medical Faculty, Kahramanmaras-Turkey ${ }^{2} \mathrm{MD}$ Departments of Psychiatry, Education and Research Hospital, Erzurum-Turkey ${ }^{3} \mathrm{MD}$, Departments of Psychiatry, Education and Research Hospital, Rize-Turkey ${ }^{4} \mathrm{MD}$, Department of Public health, Faculty of Medicine, Malatya-Turkey

${ }^{5} \mathrm{MD}$, Department of Endocrinology, Faculty of Medicine, Kahramanmaras-Turkey

Yazıșma Adresi / Address reprint requests to: Erman Bagcioglu, MD, Education And Research Hospital, Erzurum-Turkey

Elektronik posta adresi / E-mail address: ermanbagciog̃lu@yahoo.com

Kabul tarihi / Date of acceptance: 19 Ekim 2012 / October 192012

Bag̃ıntı beyanı:

E.B., E.B., B.B., A.O., M.O., M.F.K.: Yazarlar bu makale ile ilgili olarak herhangi bir cıkar çatıșması bildirmemiștir.

Declaration of interest:

E.B., E.B., B.B., A.O., M.O., M.F.K.: The authors reported no conflict of interest related to this article.

\section{INTRODUCTION}

Diabetes mellitus (DM), is a somatic illness which has psychobiological and psychosocial dimensions (1,2). DM, which has an approximate prevalence of $7.2 \%$ in Turkey, has both growing in prevalence and importance (3).

The relationship between psychiatric and endocrinological illnesses is important because of the shared biological background. Blood glucose level and its dysregulation directly affect brain and mental functions and conversely blood glucose is affected from both mental and emotional changes (4). Many studies reported that DM is seen in high comorbidity in psychiatric disorders $(5,6)$. It is generally believed that psychiatric illness can adversely affect blood glucose regulation either through neuroendocrine pathways or by disrupting the behaviors necessary for diabetic self-care (7). However, it was observed that psychiatric diagnosis did not correctly predict diabetes control (8). Thus, researchers focused on the relationship between personality traits and glucose regulation. In Stabler et al.'s study, patients with insulin dependent DM were divided into two groups as type $A$ and type $\mathrm{B}$ according to their behavior patterns and it was found that only type A subjects showed hyperglycemic response to stress (9). Graue et al. found, in the study of 103 adolescents with diabetes, that greater use of active coping was related to better HbAlc and higher diabetes life satisfaction (10). Lane et al. reported that there were 
positive relationships between higher neuroticism and good glycemic control and between higher altruism and poor glycemic control (11). Grylli et al. investigated the relationship of eating disorder, glycemic control, depression, and temperament and character inventory in adults with type 1 diabetes. This was the first study using Cloninger's personality model in adult type 1 diabetes patients. This study led to further studies because it detected a difference in the personality characteristics of type 1 diabetics that develop eating disorder or not (12). In a study, using Cloninger's earlier version of TCI, it was found that diabetic patients with opportunistic personality features had poor metabolic control and this patient group consisted of people who can't delay satisfaction (13). Finally, we thought that the studies investigating the personality traits in patients with diabetes are important because they help us understand the pathogenesis of diabetes and effective management of glucose levels better.

Thus, we aimed to investigate the personality structure of patients with diabetes mellitus via a new psychobiological inventory, the temperament and character inventory (TCI) developed by Cloninger 1987 (13). Theoretical model of Cloninger based psychobiological model of personality, assume that personality can be dissected into temperament and character and interaction between temperament and character. Temperament dimensions are hypothesized to be determined genetically and inherent features that do not change throughout an individual's life span. Character dimensions are postulated to be determined mostly by environment.

\section{MATERIALS AND METHODS}

Our study elected naturalistically 50 type 2 diabetes patients who applied to outpatient clinics of endocrinology at the Medical School of Kahramanmaras Sutcuimam University between the years of 2007-2010. The participants were selected in a naturalistic manner. Inclusion criteria were based on being within 18-65 age group, having type 2 diabetes and being able to fill in questionnaires by oneself. Exclusion criteria were as follows: using any psychotropic medication, comorbid diabetes by a chronic illnesses (i.e other endocrine diseases, neurological disorder, systemic diseases, chronic obstructive pulmonary disease, arthritis), and diabetes-related complications including proliferative retinopathy, neuropathy and microalbuminuria. Control group was consisted of 50 healthy volunteers working as staff in the hospital or people who applied to the hospital for check up. The participants gave written informed consent confirming participation. The subjects presented to the Endocrinology Unit after an overnight fast. A fasting venous blood sample was taken between 8:00 and 9:00 a.m. Each participant attended a second laboratory session and provided a second blood sample for postpyrandial blood glucose, $\mathrm{HgbAlc}$, urea and creatinine. Heights and weights were measured by the clinic staff. BMI was calculated as body weight $(\mathrm{kg})$ divided by the square of the height $\left(\mathrm{m}^{2}\right)\left(\mathrm{kg} / \mathrm{m}^{2}\right)$. Temperament and character inventory (TCI), Montgomery-Asberg Depression Rating Scale (MADS), Hamilton Anxiety Rating Scale (HAM-A) were administered to both study and control group members and the participants with incomplete results were excluded.

Temperament and Character Inventory (TCI): This inventory, consisting of 240 yes/no questions was introduced by Cloninger as Tridimensional Personality Questionnaire (14). Having its origins in biopsychosocial model, the inventory is further developed by Cloninger. In 1991 three character and one personality feature was added making the inventory seven dimensional and its name was changed as Temperament and Character Inventory (15) According to temperament dimensions: novelty seeking (NS) has four subscales (NS1: exploratory excitability; NS2: impulsivity; NS3: extravagance; NS4: disorderliness); harm avoidance (HA) has four subscales (HA1: anticipatory worry; HA2: fear of uncertainty; HA3: shyness; HA4: fatigability); and reward dependence (RD) has three subscales (RD1: sentimentality; RD3: attachment; RD4: dependence) and persistence (P). According to character dimensions; self directedness has five subscales (SD1: responsibility; SD2: purposefulness; SD3: resourcefulness; SD4: self acceptance; SD5: congruent second nature), cooperativeness has 5 subscales (CO1: social acceptance; $\mathrm{CO} 2$ : empathy; $\mathrm{CO} 3$ : helpfulness; CO4: compassion; $\mathrm{CO} 5$ : principled) and self transcendence has 3 subscales (ST1: self forgetfulness; ST2: transpersonal identification; ST3: spiritual acceptance). The validity and reliability study of Turkish version was made by Kose et al. (16). 
Table 1: Metabolic parameters of patients and controls

\begin{tabular}{lccc} 
& Patients & Controls & P \\
\hline BMI & $30.22 \pm 6.93$ & $26.50 \pm 4.18$ & $0.002^{*}$ \\
FPG $(\mathrm{mg} / \mathrm{dl})$ & $182.98 \pm 88.43$ & $84.30 \pm 9.03$ & $<0.001$ \\
PPG $(\mathrm{mg} / \mathrm{dl})$ & $260.30 \pm 156.79$ & $137.98 \pm 15.68$ & $<0.001$ \\
HbA1c & $7.72 \pm 2.27$ & $5.02 \pm 0.49$ & $<0.001$ \\
Bun & $12.22 \pm 5.6$ & $12.00 \pm 2.1$ & 0.797 \\
Creatinine & $0.85 \pm 0.5$ & $0.81 \pm 0.1$ & 0.61 \\
\hline
\end{tabular}

" $p<0.05$, FPG: Fasting plasma glucose, PPG: Postpyrandial plasma glucose

\section{Montgomery Asberg Depression Rating Scale}

(MADRS): is a scale that can evaluate state of patients with depressive symptoms and severity of somatic complaints. It consists of 10 items and each item is scored 0-6 (17). Validity and reliability study of Turkish version was made by Ozer et al. in 2001 (18).

Hamilton Anxiety Rating Scale (HAM-A): This form is designed to measure patients' anxiety levels and also to measure the symptom and severity distribution of anxiety across body systems. It is a simple scale consisting of 14 questions which evaluates mental and somatic symptoms and encoded by the interviewer marking on the scale. It is used to measure the anxiety level of the patient in last 72 hours (19). Validity and reliability study of Turkish version was made by Yazici et al. (20).

\section{Statistical Analyses}

Patient and control groups were compared with chisquare test; parametric data were examined with Student-t test and non-parametric data with MannWhitney U test. All the statistical analyses were made with SPSS 16 software.

\section{RESULTS}

A total of 50 patients with type 2 diabetes and 50 healthy controls were included in this study. The mean age for patient group was $44.7 \pm 8.6$ years and $40.8 \pm 7.6$ for control group and the difference was not significant $(\mathrm{p}=0.18)$. Forty four percent $(\mathrm{n}=22)$ of the patient group were male and $56 \%(n=28)$ were female; twenty five $(50 \%)$ of the control group were male and $25(50 \%)$ were female. There were no significant differences between the two
Table 2: Depression and anxiety scores of the patient and control groups

\begin{tabular}{lccc} 
& $\begin{array}{c}\text { Patients } \\
\text { Mean } \pm S D\end{array}$ & $\begin{array}{c}\text { Control } \\
\text { Mean } \pm S D\end{array}$ & P \\
\hline HAM & $12.8 \pm 6.9$ & $4.9 \pm 5.1$ & $<0.001$ \\
MADRS & $9.4 \pm 8.6$ & $5.2 \pm 6.7$ & 0.009 \\
\hline$" \mathrm{p}<0.05$ & & &
\end{tabular}

groups ( $\mathrm{p}=0.55)$. Education and marital status were not significantly different between diabetic patients and healthy controls ( $\mathrm{p}=0.37$ and $\mathrm{p}=1.00$, respectively). As shown table 1 , there was no significant difference between patients and control groups in BUN and Creatinine levels ( $\mathrm{p}=0.797, \mathrm{p}=0.619$, respectively). BMI, HA1c, fasting plasma glucose and postprandial plasma glucose levels were significantly higher in patient group than the control group. In diabetic patients, Hamilton anxiety and MADRS scores were significantly higher than healthy group $(\mathrm{p}<0.001$ and $\mathrm{p}=0.009$, respectively) (Table 2$)$.

In temperament dimensions, there were no significant differences between groups according to total/sub dimensions of novelty seeking, reward dependence, and persistence scores $(p>0.05)$. Although total and most of the harm avoidance subscores did not differ between groups ( $p>0.05$ ), the only significance was at HA4 (fatigability) subscore that diabetic patients were more fatigued than controls $(\mathrm{p}<0.001)$ (Table 3 ).

In character dimensions; total scores of all characters did not significantly differ between groups ( $p>0.05$ ) However, score of third subdimension in cooperativeness character (helpfulness) was significantly higher in diabetic patients $(p<0.05)$. On the contrary, third subdimension of self directedness character (resourcefulness) was significantly lower in patients than healthy controls $(\mathrm{p}<0.05)$ (Table 4$)$. 
Table 3: Comparison of temperament dimension between patients and controls

\begin{tabular}{lccc} 
Temperament subdimensions & $\begin{array}{c}\text { Patients group } \\
\text { Mean - SD }\end{array}$ & $\begin{array}{c}\text { Healthy controls } \\
\text { Mean - SD }\end{array}$ & P \\
\hline NS (novelty seeking) & $18.54-4.45$ & $18.54-4.20$ & 1.000 \\
NS1 (exploratory excitability) & $5.50-1.93$ & $6.06-1.87$ & 0.147 \\
NS2 (impulsivity) & $3.64-1.61$ & $3.44-1.68$ & 0.545 \\
NS3 (extravagance) & $4.00-1.71$ & $3.96-2.07$ & 0.917 \\
NS4 (inorderliness) & $5.40-1.71$ & $5.08-1.62$ & 0.341 \\
HA (harm avoidance) & $21.3-5.40$ & $19.10-4.69$ & 0.29 \\
HA1 (anticipatory worry) & $5.94-2.05$ & $5.40-1.94$ & 0.189 \\
HA2 (fear of uncertainty) & $7.56-1.26$ & $7.46-1.47$ & 0.717 \\
HA3 (shyness) & $2.70-1.80$ & $2.40-1.74$ & 0.401 \\
HA4 (fatigability) & $5.18-1.90$ & $3.73-1.99$ & $0<0.001$ \\
RD (reward dependence) & $14.5-2.70$ & $13.68-2.80$ & 0.140 \\
RD1 (sentimentality) & $7.88-1.43$ & $7.32-1.57$ & 0.066 \\
RD3 (attachment) & $4.28-1.49$ & $4.14-1.45$ & 0.637 \\
RD4 (dependence) & $2.34-1.17$ & $2.22-1.40$ & 0.644 \\
P (persistence) & $5.18-1.55$ & $5.64-1.58$ & 0.151
\end{tabular}

Table 4: Comparison of character dimension between patients and controls

\begin{tabular}{lccc} 
Character subdimension & $\begin{array}{c}\text { Patient group } \\
\text { Mean - SD }\end{array}$ & $\begin{array}{c}\text { Healthy controls } \\
\text { Mean - SD }\end{array}$ & P \\
\hline SD (self directedness) & $24.9-6.15$ & $27.12-5.75$ & 0.077 \\
SD1 (responsibility) & $4.32-2.11$ & $4.36-1.71$ & 0.917 \\
SD2 (purposefulness) & $5.40-1.57$ & $6.02-1.96$ & 0.086 \\
SD3 (resourcefulness) & $2.42-1.23$ & $3.16-1.28$ & 0.004 \\
SD4 (self acceptance) & $5.10-2.30$ & $5.50-2.29$ & 0.387 \\
SD5 (congruent second nature) & $7.74-2.38$ & $8.12-1.99$ & 0.389 \\
C (cooperativeness) & $29.0-5.42$ & $29.47-5.84$ & 0.704 \\
C1 (social acceptance) & $5.46-1.77$ & $6.00-1.49$ & 0.103 \\
C2 (empathy) & $3.56-1.28$ & $3.97-1.39$ & 0.122 \\
C3 (helpfulness) & $4.96-1.39$ & $4.41-1.16$ & 0.040 \\
C4 (compassion) & $7.50-3.00$ & $7.40-2.68$ & 0.873 \\
C5 (principled) & $7.56-1.75$ & $7.92-1.65$ & 0.293 \\
ST (self transcendence) & $20.3-4.23$ & $19.78-4.49$ & 0.553 \\
ST1 (self forgetfulness) & $5.18-1.88$ & $5.42-1.84$ & 0.521 \\
ST2 (transpersonal identification) & $6.28-1.93$ & 0.063 \\
ST3 (spiritual acceptance) & $8.84-1.84$ & $8.54-1.99$ & 0.960 \\
\hline "P<0.05 & & & \\
\end{tabular}

\section{DISCUSSION}

Although most studies have showed that there are significant personality differences between diabetes and non-diabetes populations, there is wide divergence with respect to diabetes personality profile. Our primary goal was to test the hypothesis that some personality traits (measured by TCI ) are related to type 2 diabetes and this relationships might be effective in glucose control. In our study, temperament and character profiles of patients showed some significant differences compared to normal controls. Previous studies have suggested that some personality traits are specific to diabetes and the glycemic control can be related to these personality traits. Weibe et al. found that worries about diabetes and negative affect (trait anxiety) may have negative impact on disease management and glycemic control (21). Brickman showed that type 1 diabetic patients with high conscientiousness and low neuroticism had renal deterioration times that were 12 years longer than patients with low conscientiousness (22). In Yoda et al. study, patients with type 2 were divided into two clusters based 
on the TCI results. Patients in cluster 1 were obsessional and the patients in cluster 2 were described as histrionic. The authors concluded that diabetes self-management support should be designed according to psychological characteristic subtypes of patients because of differences in glucose control in both groups (23).

Many studies reported that patients with diabetes demonstrate significantly more anxiety and depressive symptoms than the general population $(24,25,26)$. The prevalence of depressive disorder in patients with type 2 diabetes ranges from 10.9-32.9\% (27). The mechanisms underlying relationship between depression and diabetes are still unclear (28). In our study, as expected, depression scores were found higher in patients group than in control group.

Our study revealed that diabetic patients had modest different personality features measured with TCI than controls. DM is a chronic metabolic illness affecting many systems. As in many chronic illnesses individuals develop some behavioral patterns in accordance with disease coping skills and so their adaptation, life, capabilities and functionality differ. Whether the detected difference should be taken directly as a personality feature or it should be considered to be the result of the depressive mood, anxiety disorder, and/or chronic illness is not known.

In our study only HA4 (fatigability) subscale from the TCI was higher in patients than in controls. This means that diabetics have more fatigue than controls. People with high fatigability tend to be more inactive, live sedentarily and gain weight in time. As physical activity can play a role in the improvement of glucose tolerance and insulin sensitivity, fatigability appears to be risk for the development of type 2 diabetes independent from obesity $(29,30)$. It is likely that individuals with this personality trait have increased type 2 diabetes risk. Harm avoidance, mostly with all its subscales, is found to be high in depression and so it can be evaluated as a specific feature of depression $(31,32)$. In this study, we could not demonstrate any significant difference between two groups regarding harm avoidance, although patients with type 2 diabetes had significantly higher depression scores than healthy controls. To determine whether this condition is a specific feature of diabetic patients in the early stage non-complicated diabetes should be evaluated in further research.

In our study we failed to find a difference in TCI character features except a lower SD3 (resourcefulness) score and a higher C3 (helpfulness) score. As indicated by low SD3 scores diabetic patients seem to be more passive than healthy people. Diabetic patients are dealing with chronic treatment and deleterious effects of diabetes in their lives. Thus, in most of time they are engaged in concerns about their bodies which might come out as inability to cope with or to develop new strategies. Individuals with high C3 (helpfulness) scores understand the preferences and needs of others as well as their own and they try to cooperate with others. This personality trait may be useful in adherence to diabetic regime, if they are asked to comply with fixed list of do's and don'ts about diabetes care. Lack of diabetic complications in our patient sample might lead us to suspect the relationship between glycemic control and personality. However this finding is not in line with an earlier study (33) that showed no relationship. Nevertheless, further observations from longitudinal studies are needed to clarify this point.

There are several limitations to the present study, and results should be interpreted with caution. First, our sample is relatively small. These data must be replicated in larger samples of patients. Second, we did not use another chronic disease group, but healthy volunteers as control group. It may be more useful to explore personality profile in patients with type 2 diabetes.

In summary, based on our results, patients with type 2 diabetes mellitus may have significantly different temperament and character properties than normal population and patients with chronic disease may exhibit different personality profile. These results point to the idea that personality assessment should to be considered as an important factor in medical management and long term glycemic control of type 2 diabetes. 


\section{References:}

1. Alam R, Sturt J, Lall R, Winkley K. An updated meta-analysis to assess the effectiveness of psychological interventions delivered by psychological specialists and generalist clinicians on glycaemic control and on psychological status. Patient Educ Couns. 2009;75:25-36.

2. Steed L, Cooke D, Newman S. A systematic review of psychosocial outcomes following education, self-management and psychological interventions in diabetes mellitus. Patient Educ Couns. 2003;51:5-15.

3. Satman I, Yllmaz T, Sengül A, Salman S, Salman F et al. Populationbased study of diabetes and risk characteristics in Turkey: results of the Turkish diabetes epidemiology study (TURDEP). Diabetes Care. 2002;25:1551-6

4. B.Kaplan and V.Sadock. Kaplan and Sadock's Comprensive Texbook of Psychiatry 8th edition. 2007:701-792.

5. Anderson RJ, Freedland KE, Clouse RE, Lustman PJ. The prevelance of comorbid depression in adults with diabetes: A meta-analysis. Diabetes Care. 2001;24:1069-78.

6. Medved V, Jovanovic N, Knapic VP. The comorbidity of diabetes mellitus and psychiatric disorders. Psychiatr Danub. 2009;21:585-8.

7. Kovacs M, Mukerji P, Iyengar S, Drash A. Psychiatric disorder and metabolic control among youths with IDDM. Diabetes Care. 1996;19:318-23

8. Lustman PJ, Frank BL, McGill JB. Relationship of personality characteristics to glucose regulation in adults with diabetes. Psychosom Med. 1991;53:305-12.

9. Stabler B, Surwit RS, Lane JD, Morris MA, Litton J, Feinglos MN. Type A behavior pattern and blood glucose control in diabetic children. Psychosom Med. 1987;49:313-6.

10. Graue M, Wentzel-Larsen T, Bru E, Hanestad BR, Sovik O. The coping styles of adolescents with type 1 diabetes are associated with degree of metabolic control. Diabetes Care. 2004;27:1313-7.

11. Lane JD, McCaskill CC, Willams PG, Parekh PI, Feinglos MN, Surwit RS. Personality correlates of glycemic control in type 2 diabettes, Diabetes Care. 2000;23:1321-5.

12. Gyrlli V, Hafferl- Gattermayer A, Wagner G, Schober E, Karwautz A. Eating Disorders and Eating Problems Among Adolescent With Type I Diabetes: Exploring Relationships With Temperament and Character; J Pediatr Psychol. 2005;30:197-206.

13. Cloninger CR. A systematic method for clinical description and classification of personality variants. A proposal. Arch Gen Psychiatry. 1987;44:573-88.

14. Cloninger CR, Pryzbeck TR, Svrakic DM. Tridimentional Personality Questionnare: US Normative Data. Psychol Rep. 1991;69:1047-57.

15. Cloninger CR, Svrakic DM, Pryzbeck TR. A Psychobiological model of Temperament and Character. Arch Gen Psychiatry. 1993;50:975-90.

16. Kose S, Sayar K, Kalelioglu Ü, Aydın N, Ak İ, Kırpınar İ, Reeves RA, Przybeck TR, Cloninger CR. Mizac ve Karakter Envanteri (Türkçe TCI): Geçerlik,Güvenirliği ve Faktör Yapısı. Klinik Psikofarmokoloji Bülteni. 2004;14:107-31.
17. Montgomery SA, Asberg M: A new depression scale to be sensitive to change. Br J Psychiatry. 1979;134:382-9.

18. Ozer S, Demir B,Tuğal O, KabakçıE, Yazıcı MK. MontgomeryAsberg Depression Scale: reliability and vulnerability between scales. Türk Psikiyatri Dergisi. 2001;12:185-94.

19. Hamilton M. The assessment of anxiety states by rating. Br J Med Psychol 1959; 32:50-55.

20. Yazıcı MK, Demir B, Tanrıverdi N. Hamilton Anxiety scale reliability and vulnerability between scales. Journal of Turkish Psychiatry. 1988;9:114-7.

21. Weibe DJ, Alderfer MA, Palmer SC, Lindsay R, Jarett L. Behavioral self-regulation in adolescents with type 1 diabetes: negative affectivity and blood glucose symptom perception. J Consult Clin Psychol. 1994;62:1204-12.

22. Brickman AL, Yount SE, Blaney NT, Rothberg ST, De-Nour AK. Personality traits and long term status: the influence of neuroticism and conscienttiousness on renal deterioration in type-1 diabetes. Psychosomatics. 1996;37:459-68.

23. Yoda N, Yamashita T, Wada Y, Fukui M, Haseqawa G, Nakamura N, Fukui K. Classification of adult patients with type 2 diabetes using the Temperament and Character Inventory; Psychiatry. Clin Neurosci. 2008;62:279-85.

24. Schneider KL, Pagoto SL, Handschin B, Panza E, Bakke S, Liu Q, Blendea M, Ockene IS, Ma Y. Design and methods for a pilot randomized clinical trial involving exercise and behavioral activation to treat comorbid type 2 diabetes and major depressive disorder. Ment Health Phys Act. 2011;4:13-21.

25. Dantzer C, Swendsen J, Maurice-Tison S, Salamon R. Anxiety and depression in juvenile diabetes: a critical review. Clin Psychol Rev. 2003;23:787-800.

26. Balhara YP, Sagar R. Correlates of anxiety and depression among patients with type 2 diabetes mellitus. Indian J Endocrinol Metab. 2011;15:550-4.

27. Ali S, Stone MA, Peters JL, Davied MJ, Khunti K. The prevalence of co-morbid depression in adults with type 2 diabetes: a systematic review and meta-analysis. Diabet Med. 2006;23:1165-73.

28. Nouwen A, Winkley K, Twisk J, Lloyd CE, Peyrot M, Ismail K, Pouwer F;European Depression in Diabetes (EDID) Research Consortium. Type 2 diabetes mellitus as a risk factor the onset depression: a systematic review and meta-analysis. Diabetologia. 2010;53:2480-6.

29. Schranz A, Tuomilehto J, Marti B, Jarrett RJ, Grabauskas V, Vassallo A. Low physical activity and worsening of glucose tolerance: results from a 2-year follow-up of a population sample in Malta. Diabetes Res Clin Pract. 1991;11:127-36.

30. Ramachandran A, Snehalatha C, Mary S, Mukesh B, Bhaskar AD, Vijay V; Indian Diabetes Prevention Programme (IDPP). The Indian Diabetes Prevention Programme shows that lifestyle modification and metformin prevent type 2 diabetes in Asian Indian subjects with impaired glucose tolerance (IDPP-1). Diabetologia. 2006;49:289-97. 
31. Nery FG, Hatch JP, Nicoletti MA, Monkul ES, Najt P, Matsuo $\mathrm{K}$, Cloninger CR, Soares JC. Temperament and character traits in major depressive disorder: influence of mood state and recurerrence of episodes. Depress Anxiety. 2009;26:382-8.
32. Hansenne M, J Regger, Pinto E, Kjiri K, Ajamier A, Ansseau M. Temperament and Character Inventory (TCI) and depression. J Psychiatr Res. 1999;33:31-6.

33. Mazze RS,Lucido D,Shamoon H. Psychological and social correlates of glycemic control. Diabetes Care. 1984;7:360-6. 